\title{
RENAL PAPILLARY NECROSIS IN CHILDHOOD
}

\author{
BY \\ G. A. STIRLING \\ From the Royal Victoria Infirmary, Newcastle upon Tyne*
}

(RECEIVED FOR PUBLICATION JUNE 12, 1957)

Necrosis of the renal papillae is an uncommon lesion in adults, and, judging from the scarcity of reports in the literature, must be even less common in childhood. In adults it is usually associated with diabetes mellitus, suppurative pyelonephritis, and chronic urinary obstruction. The course of the disease is generally acute, and in the presence of infection clinically difficult to distinguish from suppurative pyelonephritis. The lesion may be bilateral or unilateral and may involve only the tip of the papilla or the entire pyramid up to the cortico-medullary junction. It is frequently overlooked at necropsy.

So far only three reports of the lesion occurring in childhood have been traced. Edmondson, Martin, and Evans (1947) reported it in a child of 11 years with a urinary infection, and Tamaki and Whitman (1952) in a 2-month-old infant with a gastro-intestinal disorder. Swartz (1954) described the condition in an infant aged 5 months with meningitis, and in this instance the lesion was associated with thrombosis of the renal interlobar veins.

The main purpose of this paper is to report four cases in children which have come to necropsy at this hospital since 1950, and to suggest a pathogenesis for one of them.

\section{Case Reports}

Case 1.-A child aged 4 years and 9 months was transferred to the Royal Victoria Infirmary on November 8, 1951, eight days after an accident in which she sustained extensive burns involving the whole trunk, left buttock, and both arms. Haemoglobin was $66 \%$ and she was transfused with blood. On the twelfth day after admission her condition was poor and she was given oxygen, and chloromycetin was added to the penicillin which had previously been given. A further transfusion was given, but her condition deteriorated and she died 22 days after the accident.

Laboratory Findings. - On November 20 analysis of urine showed 4 R.B.C.s and 240 pus cells per c.mm., a trace of albumin, and $2.5 \mathrm{~g}$./ litre chlorides. On the next day $320 \mathrm{mg} . \%$ sodium, $397 \mathrm{mg} . \%$ chlorides, and

* Present address: University College of West Indies, Jamaica.
$25.1 \mathrm{mg} . \%$ potassium. The alkali reserve was $32.8 \mathrm{ml}$. $\mathrm{CO}_{2} / 100 \mathrm{ml}$. serum. The concentration of urea in the cerebrospinal fluid was $80 \mathrm{mg} . \%$.

Ps. pyocyanea was detected in blood culture and was sensitive to chloromycetin.

Necropsy Findings.-Both kidneys were swollen and showed on the capsular and cut surfaces scattered groups of small abscesses in the cortices and medullae. The medullae were deeply congested and the cortices relatively pale whilst on the right side there was an irregular zone of anaemic infarction extending to the capsular surface. The bladder was inflamed. The ureters were normal. The renal veins were patent.

Of the remaining organs, the heart was normal, the liver congested, and the lungs the seat of a bronchopneumonia.

The kidneys showed on each side a suppurative pyelonephritis with colonies of pleomorphic Gramnegative bacilli scattered among the inflammatory exudate. The papillae of the left kidney were necrotic, but dilated collecting tubules stuffed with debris and degenerate leucocytes could be distinguished. Zones of inflammation separated the necrotic tissue from the viable renal parenchyma. Convoluted tubules were dilated and contained eosinophilic material, but the glomeruli were unaffected except for those involved by the suppuration and a small recent infarct on the right side. Small venous thrombi were seen on both sides in the vicinity of the suppuration and a few tubulo-venous aneurysms were noted in the juxtamedullary areas.

The liver showed a well-marked centrilobular necrosis.

The pancreas appeared normal.

The right adrenal showed small haemorrhages and thrombi with limited cortical necrosis, and in the left the medulla was infiltrated by a ganglioneuroma.

This was a case of unilateral papillary necrosis in a child suffering from burns, pyocyanea septicaemia, and acute suppurative pyelonephritis.

Case 2. - This baby girl aged 8 weeks was admitted on April 10, 1950, with a three-week history of passing green stools. On examination she was an ill, dehydrated baby with palpable kidneys, and the urine contained albumin, red blood corpuscles, and pus cells. She was treated with penicillin and sulphonamides. Four days after admission, despite the absence of vomiting and diarrhoea, she was de- 


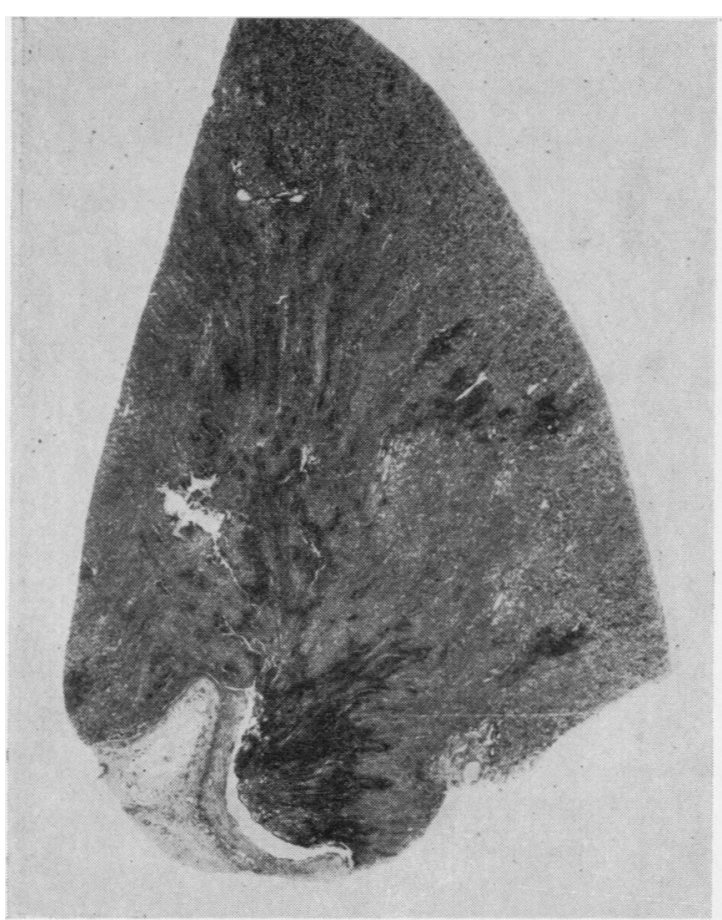

FIG. 1.-Case 1: a necrotic papilla and abscesses in the medulla and cortex. Haematoxylin and eosin, $\times 4$.

hydrated, with a blood urea of $187 \mathrm{mg} . \%$, and fluids were given by subcutaneous drip. Ten days after admission she suddenly became worse and in a short time the fontanelle had become grossly sunken. Eschatin was given four hourly. Five days later the blood sodium had risen from $270 \mathrm{mg}$. to $430 \mathrm{mg}$. and the eschatin, together with normal saline which was being given by mouth, was stopped. Thereafter the child's condition worsened and 20 days after admission the breathing became periodic, the skin cold and mottled, and she died.

Laboratory Findings.-Analyses of urine gave the results per c.mm. set out below:

\begin{tabular}{c|c|c|c}
\hline Date & Red Blood Cells & Pus Cells & Casts \\
\cline { 1 - 2 } $14 / 4 / 50$ & Few & Occasional & 0 \\
$15 / 4 / 50$ & 30 & 91 & 3 \\
$19 / 4 / 50$ & 4 & 12 & \\
$26 / 4 / 50$ & Few & 1,200 & \\
$28 / 450$ & - & 490 &
\end{tabular}

Albumin + in all specimens and heavy growth of coliform organisms. Chlorides, 2.85-5 g./litre.

Blood chemistry gave the following results:

\begin{tabular}{|c|c|c|c|c|}
\hline & $\underset{\text { (mg.\%) }}{\text { Urea }}$ & $\begin{array}{l}\text { Sodium } \\
\text { (mg.\%) }\end{array}$ & $\begin{array}{c}\text { Chlorides } \\
\text { (mg.\%) }\end{array}$ & $\begin{array}{c}\text { Potassium } \\
(\mathrm{mg} . \%)\end{array}$ \\
\hline $\begin{array}{l}14 / 4 / 50 \\
17 / 4 / 50\end{array}$ & $\begin{array}{l}187 \\
120\end{array}$ & $2 \overline{270}$ & $2 \overline{288}$ & $\overline{28 \cdot 6}$ \\
\hline $\begin{array}{l}21 / 4 / 50 \\
25 / 4 / 50\end{array}$ & $\begin{array}{l}\text { Alkali reserv } \\
\begin{array}{c}76 \\
148\end{array}\end{array}$ & $\begin{array}{c}268 \\
268 \\
433\end{array}$ & $\begin{array}{c}100 \mathrm{ml} . \mathrm{se} \\
\underline{-}\end{array}$ & $21 \cdot 9$ \\
\hline
\end{tabular}

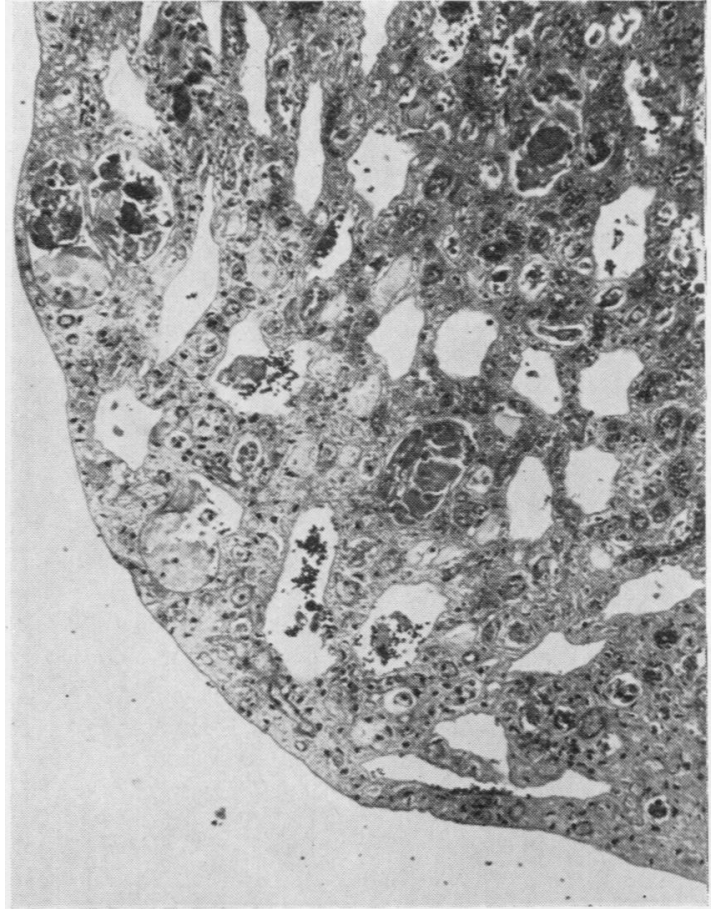

FIG. 2.-Case 1: dilated necrotic tubules filled with casts. Haematoxylin and eosin, $\times 180$.

Necropsy Findings.-Both kidneys were swollen with pale cortices and showed numerous small abscesses, but the most striking lesion was a necrosis of all the papillae which were a pale yellow. The pelves were congested and one side contained purulent material. The ureters were congested and one contained purulent material. The bladder was not obviously inflamed but showed a few petechial haemorrhages in its wall.

Except for some dilatation of the heart and oedema of the lungs the remaining organs were normal.

The necrosed papillae of the kidneys were separated from viable tissue by a zone of inflammatory reaction. Dilated collecting tubules containing amorphous material and Gram-negative bacilli could just be distinguished in areas of coagulation necrosis. All of the papillae examined were affected in varying degree and some separating from the living tissue showed obvious fibroblastic activity at their bases. Numerous calcified casts were seen in the second convoluted tubules, many of which were dilated, lined by atrophic epithelium, and contained eosinophilic material together with a few polymorphonuclear leucocytes. The glomeruli, except for those involved by suppuration, appeared normal and no thrombi or significant change was seen in the blood vessels.

The pancreas was normal.

This was a case of bilateral papillary necrosis complicating acute suppurative pyelonephritis. 


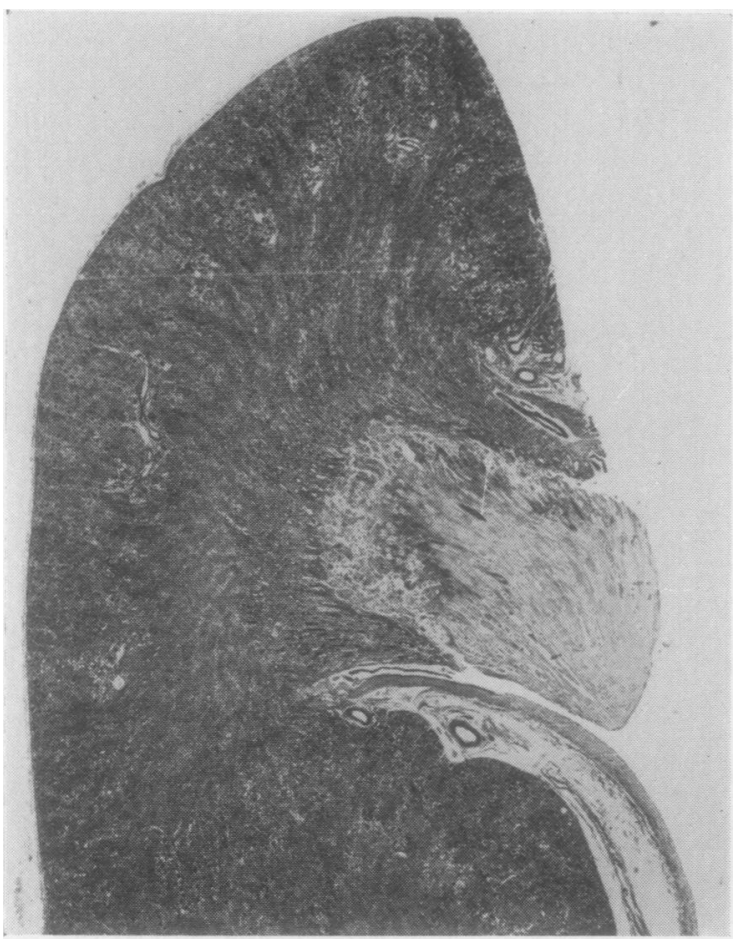

FIG. 3.-Case 2: a necrotic papilla separating from its pyramid. Haematoxylin and eosin, $\times 6$.

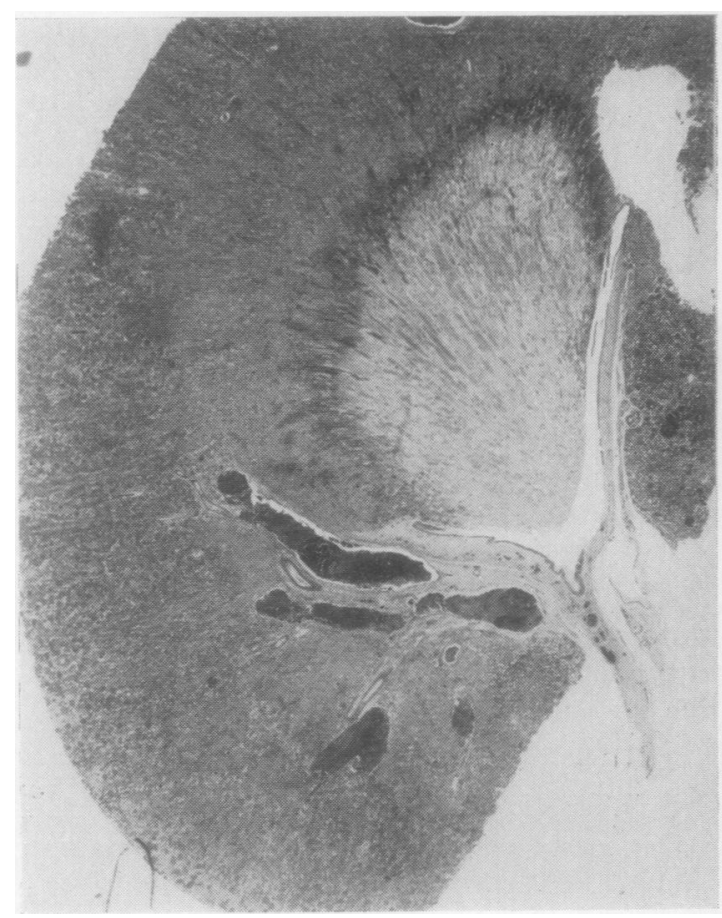

FIG. 5.-Case 3: papillary necrosis associated with renal vein thrombosis. Haematoxylin and eosin, $\times 6$.

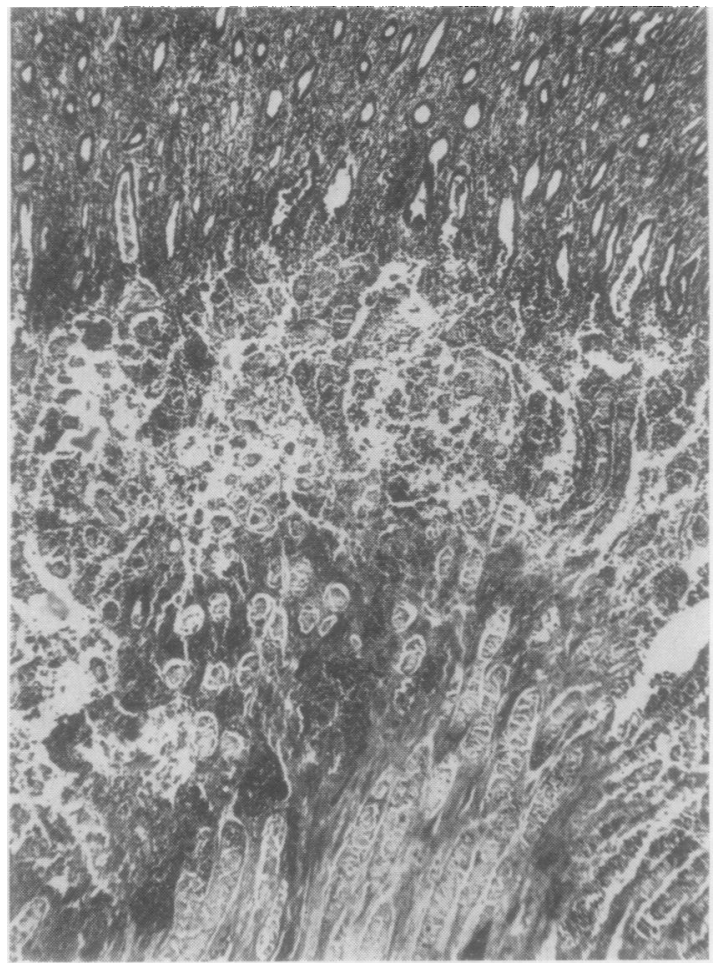

FIG. 4.-Case 2: the line of sequestration at a higher magnification. Haematoxylin and eosin, $\times 150$.

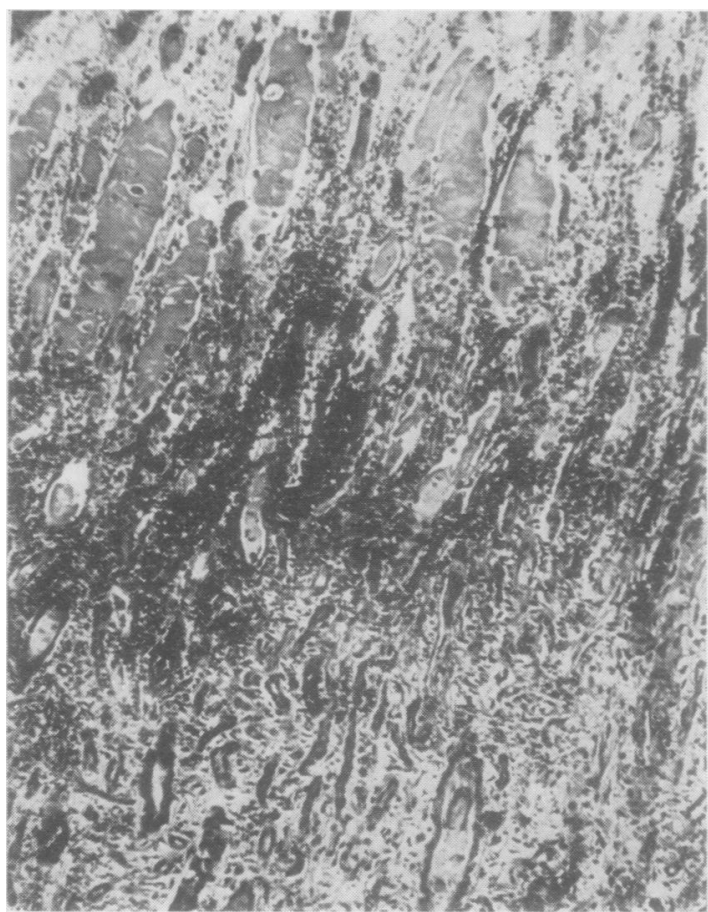

FIG.6.-Case 3: zones of hyperaemia and reaction at the base of the necrotic papilla. Haematoxylin and eosin, $\times 180$. 
The role of other factors can only be a matter of conjecture, but "eschatin" had been given and there was a severe lower nephron lesion.

Case 3.-A baby boy aged 7 months was admitted on December 30, 1951, with a history of cough from the age of 3 months. Three days before admission he began to breathe heavily, became listless, and was feverish. These symptoms gradually worsened and on the day of admission he had a fit. On examination he was an ill baby with a mottled cyanosis all over the trunk and extremities. His pulse was impalpable but hydration was moderately good. At no time while in hospital did the baby appear to be taking any notice of his surroundings, and five days after admission it was felt that he had severe irreparable cerebral damage as shown by his fluctuating temperature, occasional irregular respirations, and failure to respond to his surroundings. On the day of his death, nine days after admission, his urine contained albumin and 5 pus cells per c.mm.

Necropsy Findings. - The apices of the pyramids of the kidneys showed irregular areas of discoloration and yellowish streaking. In each renal vein a grey thrombus was seen beginning within one centimetre of the inferior vena cava and extending into the kidney substance. The ureters were patent. The mucosa of the bladder was healthy.

The brain appeared normal.

The heart showed some dilatation of its ventricles and the lungs a purulent bronchitis and bronchopneumonia, but the remaining organs were normal.

The papillae of the kidneys were involved by a coagulation necrosis in which only ghost forms of dilated cast-filled collecting tubules could be discerned. These necrosed papillae were separated from viable tissue by young vascular connective tissue. The pelvic and arcuate veins were occluded by organized thrombi whilst the interlobular veins and those of the perinephric tissue were patent and dilated.

The glomeruli appeared healthy, but many lower nephrons, particularly the second convoluted tubules, were dilated and contained eosinophilic granular casts.

The adrenals, pancreas, and brain appeared normal.

In this instance bilateral papillary necrosis was associated with thrombosis of both renal veins in a child suffering from a respiratory infection.

Case 4.-This boy aged 10 months was well until 12 days before admission when he developed a cough, sneezing, and a running nose. He vomited occasionally at this time, but a week later he began to vomit repeatedly and also had two or three loose motions each day. Micturition was normal. He had convulsions and four distinct fits before admission. On examination on December 7, 1955, he was an ill, grossly dehydrated infant with occasional twitching of the limbs. There was systolic murmur over the heart and the liver was slightly enlarged and smooth. He was transfused with glucose saline and plasma, and penicillin and sulphamezathine were given. Twelve hours after admission he had a further fit and the following day he was limp and dehydrated. The blood pressure fluctuated from $190 / 120$ to $240 / 150$ $\mathrm{mm}$. $\mathrm{Hg}$, and a rogitine test was performed. An unsuccessful attempt was made to control the blood pressure with " ansolysen." The spasticity and convulsions seemed to be controlled by repeated doses of calcium. The initial improvement in his condition was not maintained; he became increasingly oedematous, the liver descended to the umbilicus, free fluid appeared in the abdomen, and he eventually died six days after admission.

Laboratory Findings.-Analyses of urine (per c.mm.) gave the results below:

\begin{tabular}{c|c|c|c}
\hline Date & Red Blood Cells & White Blood Cells & Casts \\
\cline { 2 - 3 } $9 / 12$ & None & 4 & 0 \\
$9 / 1255$ &, & 53 & 2 \\
$10 / 12 / 55$ &, & 3 & 0 \\
\hline
\end{tabular}

Albumin trace in all specimens, specific gravity varied from 1,008 to 1010. Catheter specimen, no growth on culture.

Blood chemistry gave the following results:

\begin{tabular}{|c|c|c|c|c|c|}
\hline Date & $\begin{array}{c}\text { Urea } \\
(\mathrm{mg} . \%)\end{array}$ & $\begin{array}{l}\text { Sodium } \\
\text { (mg.\%) }\end{array}$ & $\begin{array}{c}\text { Chlorides } \\
\text { (mg.\%) }\end{array}$ & \begin{tabular}{|} 
Potassium \\
$(\mathrm{mg} . \%)$
\end{tabular} & $\underset{(\mathrm{mg} . \%)}{\mathrm{Ca}}$ \\
\hline $8 / 12 / 55$ & - & 270 & 240 & 22 & - \\
\hline \multicolumn{6}{|c|}{ Alkali reserve $61 \mathrm{ml} . \mathrm{CO}_{2}$ per $100 \mathrm{ml}$. serum } \\
\hline $\begin{array}{r}9 / 1255 \\
10 / 12 \\
0 / 55\end{array}$ & $\begin{array}{l}216 \\
188\end{array}$ & $\begin{array}{l}250 \\
240\end{array}$ & $2 \overline{19}$ & $\left|\begin{array}{l}21 \\
19\end{array}\right|$ & $\overline{7 \cdot 2}$ \\
\hline \multicolumn{6}{|c|}{ Alkali reserve 57 vol. $\mathrm{CO}_{2}$ per $100 \mathrm{ml}$. serum } \\
\hline $12 / 12,55$ & 135 & 230 & 210 & 15.8 & $7 \cdot 8$ \\
\hline \multicolumn{6}{|c|}{ Alkali reserve 51 vol. $\mathrm{CO}_{2}$ per $100 \mathrm{ml}$. serum } \\
\hline
\end{tabular}

Necropsy Findings.-Both kidneys were slightly swollen but normal in weight. The cortices were pale and showed a number of small arterial infarcts on the right side and a single small infarct on the left side. The bladder and ureters were normal. The renal veins were patent.

Of the remaining organs, the heart showed considerable left ventricular hypertrophy and a few emboli were found in the arterioles of the lungs.

The right kidney showed coagulation necrosis of a medullary pyramid. This was not sharply demarcated from the cortex but shaded off into areas of necrosis involving the convoluted tubules. In the necrotic pyramid only ghost forms of widely dilated collecting tubules filled with pale-staining amorphous material could be distinguished. The glomeruli, on the other hand, except for areas of recent infarction, were intact. Venous radicles near the boundary zone contained old hyaline thrombi and the interlobular and arcuate arteries showed muscular hypertrophy and intimal thickening. Changes in the left kidney were less severe than those in the right, but a recent arterial infarct was seen in the cortex and some proximal tubules were atrophic or showed degenerative changes. 


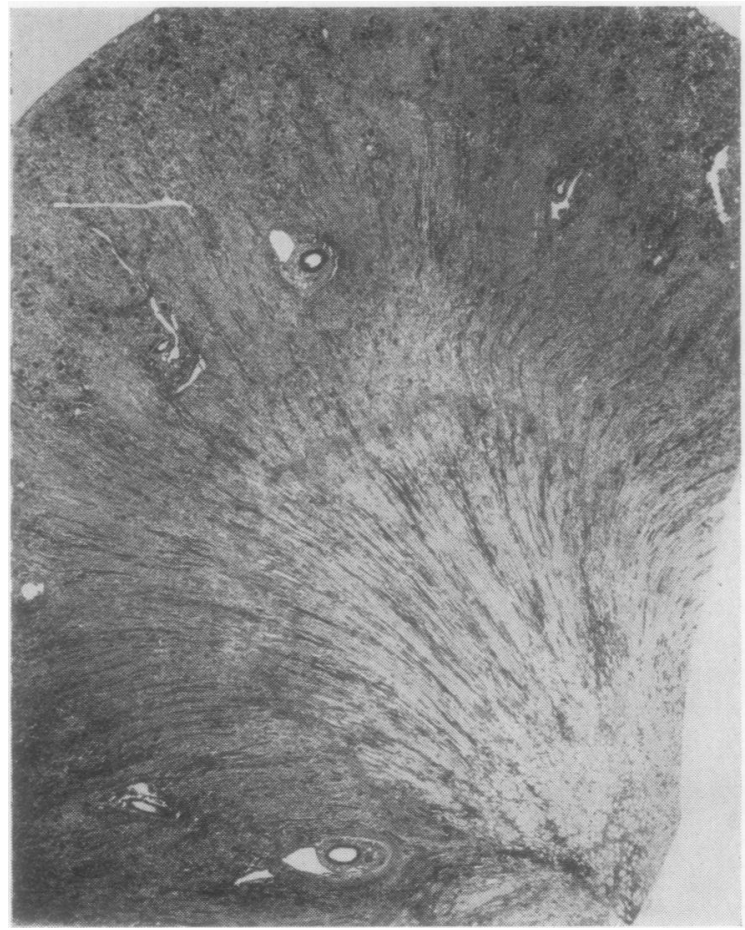

FIG. 7.-Case 4: necrosis extends to the cortico-medullary junction. Haematoxylin and eosin, $\times 3$.

The adrenals and pancreas appeared normal.

This was a case of unilateral papillary necrosis associated with a varied renal pathology, viz., arterial infarcts, mild hypertensive nephrosclerosis, thrombosis of venous radicles, and a degeneration of the lower nephron.

\section{Discussion}

A number of explanations of the pathogenesis of renal papillary necrosis have been suggested.

Friedreich (1877), reporting the condition in a man with prostatic disease and hydronephrosis, thought it was due to urinary stasis giving rise to pressure atrophy, whilst Foulon and Busser (1934) attributed the necrosis in their case to compression of the papillary vessels by a hypernephroma and material used to obtain retrograde pyelograms. Compression of vessels by a " para-amyloid substance" was blamed by Mellgren and Redell (1941). Davson and Langley (1944), however, questioned the role of pressure since the lesion was rarely seen in hydronephrosis or nephrolithiasis.

Some cases of renal necrosis were thought by Günther (1937) to be due to the staphylococcus and Bact. coli. Edmondson et al. (1947) noted the

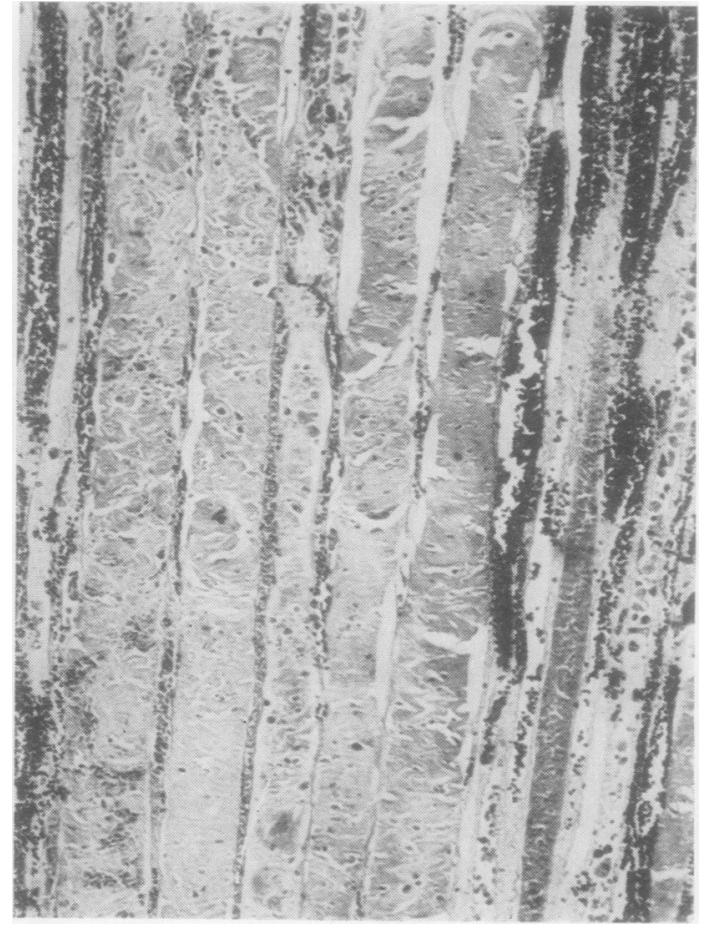

FIG. 8.-Case 4: ghost forms of necrotic tubules separated by vasa recta. Haematoxylin and eosin, $\times 180$

occasional association of the lesion with tuberculosis and actinomycosis, but they found that Staph. aureus was the chief offender, and they emphasized the importance of the necrosin and the coagulase enzyme of that organism. Davson and Langley (1944) suggested that the products of Bact. coli might conceivably have a direct toxic action on the renal papillae, but Robbins and Angrist (1949) felt that bacterial toxins alone could not account for the lesion since a similar necrosis was not found in the cortex.

Most authors from Günther (1937) onwards stress the relatively poor blood supply of the pyramids as compared with the rest of the kidney, pointing out that the bulk of the blood reaches the peritubular capillaries after it has passed through the glomeruli and that the pyramids may be particularly vulnerable to ischaemia. Robbins and Angrist (1949) suggested that a reversed Trueta shunt might produce papillary necrosis. Although Trueta, Barclay, Daniel, Franklin, and Prichard (1947) succeeded in diverting blood from the medulla to the cortex, yet papillary necrosis was not produced, suggesting that if a shunt were concerned it could not be the only 
factor, and that the papillary tissue was not particularly vulnerable to ischaemia. Nevertheless the anatomical limitation of the lesion to the pyramids and the appearances of the necrotic papillae suggest that ischaemia is concerned in some instances.

The condition has been produced in animals by methods that suggest that toxins, metabolic upset, pressure, or infection may be concerned in its pathogenesis. In 1901 Levaditi produced the lesion by poisoning animals with vinylamine and Rehns by poisoning them with tetrahydroquinoline. Borland and Jackson (1931) reported papillary necrosis in animals kept on a fat-free diet, whilst Muirhead, Vanatta, and Grollman (1950) produced the lesion by ureteral ligation and Robbins, Mallory, and Kinney (1946) observed it in experimental pyelonephritis.

The present series of cases suggests that no single factor is concerned in the pathogenesis of the lesion. Two cases ( 1 and 2 ) resembled the picture seen in some adults in that they were associated with pyelonephritis, the appearances suggesting little more than a sloughing off of infected tissue. Abscesses were present in the remaining renal parenchyma, but the papillae had suffered most and this perhaps was not unexpected since the vasa recta loop back to the cortex at this point and infected emboli and bacteria may tend to lodge there.

The remaining two cases were unusual in that papillary necrosis was associated in one instance (Case 3) with renal vein thrombosis, and in the other (Case 4) with a variety of vascular lesions, including thrombosis of the venous radicles and small arterial infarcts. In the absence of any other obvious factor it seemed likely that in both of these cases ischaemia was concerned. In Case 3 the occlusion of the main renal, pelvic, and arcuate veins would presumably affect all the renal parenchyma and therefore the peculiar limitation of the necrosis to the pyramids must be explained. Dilated venous channels in the subcapsular and perinephric tissue suggested that the cortical circulation had been maintained by a collateral circulation similar to that described by Keen (1940) in a case of obstruction of the inferior vena cava by veins piercing the capsule of the kidney. The vasa recta of the pyramidal tissue draining into the occluded arcuate veins cannot have access to this collateral circulation, and the pyramidal tissue must therefore become ischaemic. The part played by renal vein thrombosis in Case 4 can only be a matter of conjecture since the thrombi were small and numerous arterial infarcts were present.
The diagnosis of the condition is extremely difficult and the prognosis bad, but cases have been reported in adults by Alken (1938) and other authors which were diagnosed by retrograde pyelography and, when the lesion was unilateral, treated successfully by nephrectomy. The radiological changes detailed by Günther (1937) and others include dilatation of the tips of the calices, ring shadows in the necrotic papillae, and sloughed off papillae lying free in the renal pelvis. However, the pyelographic changes may not always be helpful and may be indistinguishable from those of pyelonephritis. Few other diagnostic criteria are available and a comparison of the clinical histories and laboratory data of the cases in the present series with one another reveals no one typical pattern, since the primary condition tends to mask the papillary necrosis. Nevertheless in cases of pyelonephritis or renal failure with albumin, pus cells, or red blood cells in the urine the diagnosis of renal papillary necrosis must be considered.

\section{Summary}

Four cases of renal papillary necrosis in children are reported.

In two instances the necrosis was associated with pyelonephritis, in a third with renal vein thrombosis, and in a fourth with varied vascular lesions.

The pathogenesis and diagnosis of the condition are discussed, and it is suggested that when the lesion is associated with renal vein thrombosis the survival of the cortical as opposed to the medullary tissue is due to the development of a collateral venous circulation.

I wish to thank Dr. J. Hart-Mercer for his help and permission to use the material reported here, and also Professor D. Court for his many helpful suggestions.

\section{REFERENCES}

Alken, C. E. (1938). Z. Urol., 32, 433.

Borland, V. G., and Jackson, C. M. (1931). Arch. Path. (Chicago), $11,687$.

Davson, J., and Langley, F. A. (1944). J. Path. Bact., 56, 327.

Edmondson, H. A., Martin, H. E., and Evans, N. (1947). Arch. intern. Med., $79,148$.

Foulon, P., and Busser, F. (1934). Ann. anat. path., 11, 416.

Friedreich, N. von (1877). Virchows Arch. path. Anat., 69, 308.

Günther, G. W. (1937). Münch. med. Wschr., 84, 1695.

Günther, G. W. (1937). Münch. med. W

Levaditi, C. (1901). Arch. int. Pharmacodyn., 8, 45

Mellgren, J., and Redell, G. (1941). Acta chir. scand., 84, 439.

Muirhead, E. E., Vanatta, J., and Grollman, A. (1950). J. Amer. med. Ass., 142, 627.

Rehns, J. (1901). Arch. int. Pharmacodyn., 8, 199.

Robbins, E. D., and Angrist, A. (1949). Ann. intern. Med., 31, 773

Robbins, S. L., Mallory, G. K., and Kinney, T. D. (1946). New Engl. J. Med., 235, 885 .

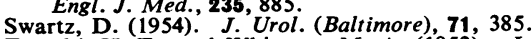

Tamaki, H. T., and Whitman, M. A. (1952). J. Amer. med. Ass., 150, 1304 .

Trueta, J., Barclay, A. E., Daniel, P. M., Franklin, K. J., and Prichard, M. M. L. (1947). Studies of the Renal Circulation. Blackwell Scientific Publications, Oxford. 